\title{
RAZPRAVE
}

\section{SOMESTJA V SLOVENIJI}

\author{
AVTORJA \\ dr. Janez Nared \\ Znanstvenoraziskovalni center Slovenske akademije znanosti in umetnosti, Geografski inštitut Antona Melika, \\ Gosposka ulica 13, SI - 1000 Ljubljana, Slovenija; janez.nared@zrc-sazu.si
}

\section{dr. Nika Razpotnik Visković}

Znanstvenoraziskovalni center Slovenske akademije znanosti in umetnosti, Geografski inštitut Antona Melika, Gosposka ulica 13, SI - 1000 Ljubljana, Slovenija; nika.razpotnik@zrc-sazu.si

DOI: $10.3986 / G V 88203$

UDK: 911.375(497.4)

COBISS: 1.01

\section{IZVLEČEK}

\section{Somestja $v$ Sloveniji}

Namen prispevka je bil opredeliti somestja $v$ Sloveniji in preveriti, na kakšen način so se ta opredeljevala do sedaj. Na podlagi analize delovne mobilnosti prebivalcev med občinami ter dopolnjevanja funkcij med posameznimi centralnimi naselji smo ugotovili, da je opredelitev somestij iz Strategije prostorskega razvoja Slovenije $z$ nekaj izjemami ustrezna, a bi jo bilo mogoče dopolniti z bolj dosledno uporabo jasnih meril za opredeljevanje somestij. Analiza je pokazala, da so somestja na podlagi mobilnosti delovne sile obsežnejša in številnejša od somestij, opredeljenih na podlagi dopolnjevanja funkcij. V prihodnje bi bilo zato smiselno uporabljati oba pristopa, saj tako lahko zaznamo ožja območja funkcijskega povezovanja med naselji v somestju kot tudi $z$ njimi povezana naselja, $k i$ jih somestjem lahko priključimo na podlagi mobilnosti delovne sile.

\section{KLJUČNE BESEDE}

geografija naselij, urbana geografija, somestja, sistem poselitve, Slovenija

\section{ABSTRACT}

\section{Conurbations in Slovenia}

This article provides a definition of conurbations in Slovenia and determines how these have been defined to date. Based on an analysis of residents' commuting for work between municipalities and complementary functions among individual central settlements, we determined that the definition of conurbations in the Spatial Development Strategy of Slovenia is appropriate, with a few exceptions, and that it could be improved through more consistent use of clear criteria for defining conurbations. The analysis shows that, when defined in terms of commuting, conurbations are more extensive and more numerous than when defined by complementary functions. In the future it would therefore make sense to use both approaches because this makes it possible to detect narrow areas of functional connectivity between settlements in a conurbation, as well as the settlements connected with them that may be included in the conurbation based on commuting.

\section{KEY WORD}

settlement geography, urban geography, conurbations, settlement system, Slovenia

Uredništvo je prispevek prejelo 9. septembra 2016. 


\section{Uvod}

Izraz somestje se v slovenskih prostorskih raziskavah in politiki pojavlja že od 1970-ih let, a načini njihovega opredeljevanja doslej niso bili jasno predstavljeni, čeprav so somestja z vpeljavo v planske dokumente (na primer Dolgoročni plan ... 1986; Strategija ... 2004) postala pomemben prostorski koncept. V prispevku smo somestja opredelili na podlagi trga dela in centralnih funkcij ter hkrati preverili, ali somestja, opredeljena v literaturi in planskih dokumentih, dejansko delujejo kot taka.

V tuji literaturi je konceptu somestij še najbližji pojem konurbacija. Obstaja pa med tem pojavom in somestji, kot jih opredeljujemo mi, pomembna razlika: konurbacija označuje gosto in sklenjeno pozidana urbanizirana območja, ki se ločijo od pretežno podeželske okolice. Se pa znotraj nje vzpostavi določena specializacija posameznih mest (Vresk 2002; ESPON 2007), tako kot to lahko poenostavljeno trdimo tudi za somestja.

V slovenski literaturi se izraz somestje pojavi pri Kokoletu $(1971,52)$, ki ugotavlja, da prihaja do prepleta gravitacijskih območij posameznih centralnih naselij, pri čemer "...gre za središča ožjih regionalnih, slej ko prej večobčinskih enot, včasih kar nekakih »somestij». Taki primeri so, Brežice, Trbovlje, Slovenj Gradec (bolje »somestje "Slovenj Gradca z Ravnami in Dravogradom) ... «. Kokole v svoji študiji navaja dopolnjevanje Jesenic s »... centralnimi dejavnostmi »srednje osnovne stopnje ... «, razmeščenimi na Bledu in v Radovljici«, kar jim zagotavlja vlogo vsaj »subregionalnega " gravitacijskega središča (Kokole 1971, 82). V podobnem smislu govori tudi o obalnem somestju, kjer »... superstruktura regionalnega pomena za južnozahodni del Slovenije ni le v Kopru, ampak tudi v Izoli, Piranu in celo v Portorožu ter Ankaranu.« (Kokole 1971, 76).

Leta 1978 Kokole ob omembi subregionalnih središč piše posamezne kraje skupaj, na primer Jesenice-Radovljica, Brežice-Krško, Ravne na Koroškem-Slovenj Gradec, leta 1987 pa omenja somestje Brežice-Krško (Kokole in Kokole 1987).

V preostalih študijah o centralnih naseljih Vrišer (1988) govori o obalnem somestju (Koper-Izola-Piran), Cigale (2002) pa o delitvi funkcij na mezoravni na primeru Raven na Koroškem in Slovenj Gradca ter na primeru Brežic in Krškega.

Pomembno vlogo somestjem pripisujejo Ravbar in sodelavci (2001, 23), ki menijo, da »... moramo v prihodnje računati še žze izraženimi manjšimi somestji (npr: Ravne-Slovenj Gradec-Dravograd, Krško-Brežice, Radovljica-Bled-Jesenice, ipd), kjer bo prav tako ob intenzifikaciji selektivne terciarizacije, prihajalo do delitve funkcij ne le med mesti, marveč tudi na urbaniziranem podeželju, ki ta somestja obdaja ... «. Somestji Koper-Izola-Piran ter Krško-Brežice uvrščajo med pomembna zaposlitvena središča, $\mathrm{z}$ vidika planske zasnove pa somestja v Slovenskem primorju, Zgornjem Gorenjskem, Zasavju, Posavju in slovenskem Koroškem uvrščajo ob bok pomembnejšim mestom (Murska Sobota, Maribor, Ptuj, Celje, Velenje, Novo mesto, Kranj, Nova Gorica, Postojna in Ljubljana), ki »... predstavljajo obvezno državno izhodišče za pripravo in oblikovanje dolgoročnih in srednjeročnih planskih aktov lokalnih skupnosti kot instrument prostorske in regionalne politike ... " (Ravbar in sodelavci 2001, 97). Somestja in delitev funkcij znotraj mestnih regij vidijo kot pomemben element v prostorskem razvoju, saj da so urbana središča industrijskih območij, kot so Velenje, Ravne na Koroškem, Jesenice ter Trbovlje s Hrastnikom in Zagorjem za preskok k središčem srednje ravni z razvojnega vidika preskromna, bodisi zaradi populacijskega zaledja bodisi zaradi ekonomske moči (Ravbar in sodelavci 2001,109).

Razmeroma podroben prikaz somestij zasledimo v Konceptu prostorskega razvoja Slovenije (Dimitrovska Andrews in sodelavci 2001), a tudi tu metodologija njihovega opredeljevanja ni predstavljena.

Pomembno vlogo v delitvi funkcij v somestjih zlasti $\mathrm{z}$ vidika aglomeracije vidijo tudi Pogačnik in sodelavci (2010), ki pa obenem ugotavljajo, da se ideja iz 1970ih o nadomeščanju manjkajočih regionalnih središč s funkcijskimi somestji z delno izjemo obalnega somestja ni uresničila. »Bližnja mestaobčinska središča - si prej konkurirajo in se prepirajo o pridobitvi kake funkcije (značilni primeri Slovenj Gradec - Ravne na Koroškem - Dravograd). Spodnje-posavsko somestje Brežice-Krško in celo Sevnica, nikoli ni prav zaživelo, saj so razdalje med mesti prevelike, mesta pa prešibka za kake skupne funkcije regio- 
nalnih ravni. Podobno velja za Zgornjegorenjsko somestje Jesenice-Radovljica/Lesce-Bled.«(Pogačnik in sodelavci 2010, 43).

V nasprotju od predhodnih avtorjev, ki se ukvarjajo s somestji kot delom sistema centralnih naselij na državni ravni, so se Miklavčič in sodelavci (2014) osredotočili na opredeljevanje somestij na lokalni ravni. Na podlagi analize 75 občinskih prostorskih načrtov ugotavljajo, da pripravljavci načrtov somestja različno razumejo. Skupno so zaznali enajst somestij, v katera je bilo vključenih 25 naselij.

Skupno gornjim študijam je, da merila za opredelitev somestij, razen da so medsebojno funkcijsko povezana, niso natančno opredeljena. Prav tako ni konsistentno navajanje naselij, ki sodijo v posamezno somestje. Zato smo ob analizi centralnih naselij v Sloveniji (Nared in sodelavci 2016; 2017; Nared, Bole in Ciglič 2016) preučili tudi opredelitev somestij, pri čemer smo ta utemeljevali na podlagi trga delovne sile ter dopolnjevanja naselij na področju centralnih funkcij. Pri tem smo si zastavili naslednja raziskovalna vprašanja:

1. Katera somestja lahko opredelimo na podlagi trga dela oziroma mobilnosti delovne sile?

2. Katera somestja lahko opredelimo na podlagi dopolnjevanja funkcij in koliko se zaznana somestja razlikujejo od somestij, opredeljenih v Strategiji prostorskega razvoja Slovenije (2004)?

3. Katera somestja lahko opredelimo upoštevaje oba predhodna načina (trg dela in dopolnjevanje funkcij). V prispevku razumemo somestja skladno z opredelitvijo Strategije prostorskega razvoja Slovenije (2004) kot skupino medsebojno povezanih mest in/ali drugih naselij, v katerih se dejavnosti razporejajo po načelu dopolnjevanja funkcij. Na Inštitutu za politiko prostora (medmrežje 1) so somestje na eni strani opredelili kot konurbacijo, z vidika našega dojemanja somestij pa je primernejša druga definicija, kjer so somestja opredeljena kot »... skupina medsebojno povezanih mest, $v$ katerih se dejavnosti razporejajo po načelu dopolnjevanja funkcij in ki skupaj tvorijo hierarhično višje vozlišče vomrežju naselij, kot bi ga vsako posamezno mesto ... «. V tem smislu govorimo o primerih, »... kjer so sicer bližnja manjša mesta fizično ločena in imajo zgodovinsko ali načrtno različne funkcije (npr. uprava, šolstvo, zdravstvo, industrija ...)...«.

\section{Metode}

Somestja smo v analizi opredelili na podlagi:

- mobilnosti delovne sile,

- centralnih funkcij in

- $\mathrm{z}$ upoštevanjem mobilnosti delovne sile in centralnih funkcij.

\subsection{Opredelitev somestij na podlagi mobilnosti delovne sile}

Pri določanju somestij na podlagi mobilnosti delovne sile smo upoštevali statistične podatke o delovno aktivnem prebivalstvu (brez kmetov) po občinah prebivališča in občinah delovnega mesta za leto 2015 (Delovno aktivno ... 2016). Pomanjkljivost podatkov je, da številna podjetja kot kraj dela vseh zaposlenih vodijo sedež podjetja, čeprav ti delajo na različnih lokacijah. Težava je tudi, da so podatki dostopni le na ravni občin, pri čemer smo jih za analizo interpretirali kot podatke, relevantne za občinsko središče. S tem smo zanemarili trg dela znotraj posamezne občine, kar vpliva na točnost rezultatov zlasti v občinah $\mathrm{z}$ več pomembnejšimi središči, kjer bi hipotetično posamezna naselja lahko izkazovala določeno stopnjo povezanosti $\mathrm{z}$ ostalimi naselji znotraj iste občine ali z naselji v sosednjih občinah.

Izhodišče pri tovrstnemu določanju somestij je, da sta posamezni občini/naselji (mesti) povezani na podlagi mobilnosti delovne sile, pri čemer ni dovolj, da ena občina/naselje zagotavlja delo delovni sili iz druge občine/naselja, temveč mora tok delavcev potekati tudi v obratni smeri, torej da druga občina/naselje zagotavlja delo primerljivemu deležu delovne sile iz prve občine/naselja. Na podlagi analize podatkov ter nekaterih dosedanjih študij o mobilnosti delovne sile (Bole 2004) smo določili dva pragova: 10-odstotni in 5-odstotni. 
10-odstotni prag pomeni, da se je iz občine/naselja A v občino/naselje B vozilo na delo vsaj $10 \%$ delovno aktivnega prebivalstva občine $\mathrm{A}$, istočasno pa se je iz občine/naselja $\mathrm{B}$ v občino/naselje A vozilo na delo vsaj $10 \%$ delovno aktivnega prebivalstva občine/naselja B.

5-odstotni prag pomeni, da se je iz občine/naselja A v občino/naselje B vozilo na delo vsaj $5 \%$ delovno aktivnega prebivalstva občine $\mathrm{A}$, istočasno pa se je iz občine/naselja B v občino/naselje A vozilo na delo vsaj $5 \%$ delovno aktivnega prebivalstva občine/naselja B.

$\mathrm{V}$ prvem primeru govorimo o močni funkcijski povezanosti naselij v somestju, v drugem pa o zmerni funkcijski povezanosti naselij v somestju. Seveda pa prihaja tudi do primerov, ko do izmenjave delovne sile med dvema občinama/naseljema prihaja, vendar pa pri tem en kraj dosega 5-odstotni prag, drugi pa 10-odstotni prag, kar kaže na asimetričnost odnosov v somestju ter večji vpliv enega od naselij.

Tako smo opredelili pare naselij, ki smo jih v naslednjem koraku povezali med sabo, če je bilo eno ali več naselij vključenih v več parov. Ko so bila v pare povezana vsa vključena naselja (več kot tri), smo somestje opredelili kot mrežno somestje, v primerih, ko vsa naselja niso bila medsebojno povezana, pa smo somestje opredelili kot verižno somestje.

Za mrežno somestje je značilno, da prihaja do izmenjave delovne sile med vsemi vključenimi naselji, torej $\mathrm{A}-\mathrm{B}, \mathrm{B}-\mathrm{C}$ in $\mathrm{A}-\mathrm{C}$, pri verižnem somestju pa le med dvema, torej $\mathrm{A}-\mathrm{B}$ in $\mathrm{B}-\mathrm{C}$, medtem ko med A-C izmenjava delovne sile ne dosega zastavljenih pragov.

\subsection{Opredelitev somestij na podlagi centralnih funkcij}

Pri določanju somestij na podlagi centralnih funkcij smo izhajali iz storitev splošnega pomena, to je storitev, ki zagotavljajo osnovno oskrbo prebivalstva. Predvsem smo upoštevali funkcije, na podlagi katerih smo opredelili stopnjo centralnosti naselij (šolstvo, zdravstvo, uprava, sodstvo; Nared, Bole in Ciglič 2016; Nared in sodelavci 2017), hkrati pa preverili nekatere dodatne funkcije (sedeže institucij) centralnega pomena: policija, banka, dom za starejše občane, vrtec, pošta, knjižnica, notariat, gledališče, muzej, Zavod za zdravstveno zavarovanje Slovenije (ZZZS), Finančna uprava Republike Slovenije (FURS), Geodetska uprava Republike Slovenije (GURS), Uprava Republike Slovenije za varno hrano, veterinarstvo in varstvo rastlin (UVHVVR), Zavod Republike Slovenije za varstvo narave (ZRSVN), Zavod za varstvo kulturne dediščine Slovenije (ZVKDS) in Zavod Republike Slovenije za zaposlovanje (ZRSZ).

Izhodišče tovrstnega opredeljevanja somestij je, da se z vidika zagotavljanja posameznih funkcij naselja medsebojno dopolnjujejo. Pri tem smo preverili somestja glede na mobilnost delovne sile ter somestja, opredeljena v Strategiji prostorskega razvoja Slovenije (2004), dodali pa smo še nekaj dodatnih somestij, kot jih lahko zaznamo na podlagi analize (Nared in sodelavci 2016; 2017). Ključno merilo za opredelitev somestij je bilo, da posamezno naselje v somestju vsaj $\mathrm{z}$ eno funkcijo dopolnjuje druga naselja $\mathrm{v}$ somestju - to pomeni, da druga naselja v somestju te funkcije nimajo in se $\mathrm{z}$ njo oskrbujejo v tistem mestu somestja, ki to funkcijo ima.

\subsection{Opredelitev somestij $\mathrm{z}$ upoštevanjem mobilnosti delovne sile in centralnih funkcij}

V tretjem koraku smo združili obe predhodni opredelitvi somestij ter izdelali skupno vrednotenje somestij.

\section{Rezultati}

\subsection{Somestja na podlagi mobilnosti delovne sile}

Na podlagi mobilnosti delovne sile smo določili 33 parov naselij, ki smo jih nato združili v 20 somestij, od katerih je eno somestje mrežno. 
Preglednica 1: Funkcijsko povezani pari naselij in somestja na podlagi mobilnosti delovne sile (preglednica 1).

par naselij (krepki tisk označuje močno funkcijsko povezanost $-10 \%$, ${ }^{\star}$ pa pomembnejše naselje v paru) somestje ( mrežno somestje)

Ajdovščina-Vipava

Ajdovščina*-Vipava

Bled-Radovljica* Bled-Radovljica-Jesenice-Kranjska Gora

Jesenice-Radovljica

Jesenice* ${ }^{\star}$ Kranjska Gora

Bovec-Kobarid

Bovec-Kobarid

Brežice-Krško

Brežice-Krško-Sevnica

Sevnica-Krško

Celje $^{*}-$ Žalec

Črna na Koroškem-Mežica*

Mežica-Prevalje

Prevalje-Ravne na Koroškem*

Celje-Žalec

Črna na Koroškem-Mežica-Prevalje-Ravne

na Koroškem-Slovenj Gradec-Dravograd

Ravne na Koroškem-Slovenj Gradec ${ }^{\star}$

Slovenj Gradec ${ }^{\star}$-Dravograd

Črnomelj-Metlika

Metlika-Črnomelj-Semič

Črnomelj ${ }^{*}$-Semič

Hrastnik-Trbovlje*

Trbovlje-Zagorje ob Savi

Izola-Koper*

Izola-Piran*

Zagorje ob Savi-Trbovlje-Hrastnik

Koper ${ }^{*}$-Piran

Kidričevo-Ptuj ${ }^{\star}$

Kidričevo-Ptuj

Kočevje-Ribnica

Kočevje-Ribnica

Križevci pri Ljutomeru-Ljutomer ${ }^{*}$

Križevci-Ljutomer

Ljubno-Nazarje*

Mozirje-Nazarje-Rečica ob Savinji-Ljubno

Mozirje-Nazarje ${ }^{*}$

Nazarje* - Rečica ob Savinji

Mirna*-Šentrupert

Mirna-Šentrupert

Muta-Radlje ob Dravi*

Muta-Radlje ob Dravi

Nova Gorica-Šempeter

Nova Gorica-Šempeter

Slovenske Konjice-Zreče

Slovenske Konjice-Zreče

Šmarje pri Jelšah-Rogaška Slatina

Šmarje pri Jelšah-Rogaška Slatina

Šentjur pri Celju-Štore

Šentjur pri Celju-Štore

Šoštanj-Velenje*

Šoštanj-Velenje

Slika 1: Somestja glede na mobilnost delovne sile.

str. 56 


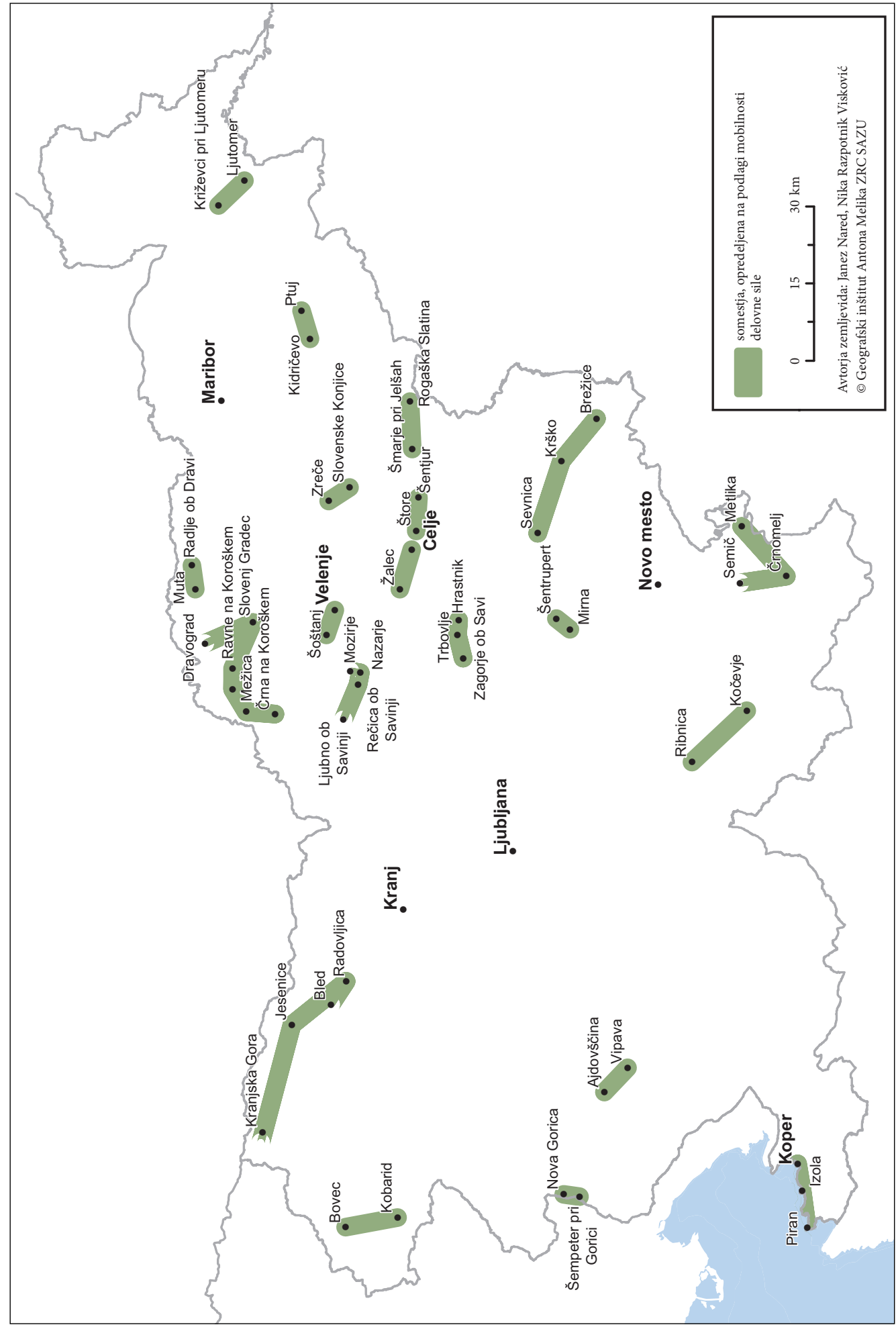


Mrežno somestje sestavljajo Koper-Izola-Piran. V njem nekoliko izstopa Koper, kamor se vozi nad $10 \%$ delovno aktivnega prebivalstva iz Pirana in Izole, več kot $10 \%$ pa se jih vozi tudi iz Izole v Piran.

Pri verižnih somestjih vključuje največ naselij koroško somestje: Črna na Koroškem-Mežica-Prevalje-Ravne na Koroškem-Slovenj Gradec-Dravograd. Glede na število vključenih naselij sledita somestji Bled-Radovljica-Jesenice-Kranjska Gora ter Mozirje-Nazarje-Rečica ob Savinji-Ljubno s po štirimi vključenimi naselji, po tri naselja imajo somestja Brežice-Krško-Sevnica, Metlika-Črnomelj-Semič, Zagorje ob Savi-Trbovlje-Hrastnik, ostala somestja pa sestavlja le en par naselij. Med temi lahko izpostavimo Novo Gorico in Šempeter, ter Slovenske Konjice in Zreče, saj sta naselji v obeh somestjih glede na mobilnost delovne sile močno funkcijsko povezani (naselji znotraj somestja si izmenjata več kot $10 \%$ delovno aktivnega prebivalstva).

\subsection{Somestja na podlagi centralnih funkcij}

Pri vrednotenju somestij na podlagi centralnih funkcij smo izhajali iz somestij na podlagi mobilnosti delovne sile in somestij, opredeljenih v Strategiji prostorskega razvoja Slovenije (2004). Ta jih opredeli kot skupino medsebojno povezanih mest in/ali drugih naselij, v katerih se dejavnosti razporejajo po načelu dopolnjevanja funkcij. Z medsebojnim povezovanjem in razmeščanjem funkcij krepijo naselja svoje vloge v urbanem sistemu.

Strategija je opredelila naslednja somestja:

a) Koper-Izola-Piran (razvija funkcije središča nacionalnega pomena; mednarodno povezovanje z Italijo in Hrvaško);

b) Brežice-Krško-Sevnica (središče nacionalnega pomena regionalnih območij; širitev svojega vpliva tudi na čezmejna območja);

c) Jesenice-Radovljica (središče nacionalnega pomena regionalnih območij);

č) Slovenj Gradec-Ravne na Koroškem-Dravograd (središče nacionalnega pomena regionalnih območij);

d) Trbovlje-Hrastnik-Zagorje ob Savi (središče nacionalnega pomena regionalnih območij);

e) Domžale-Kamnik (središča regionalnega pomena);

f) Šmarje pri Jelšah-Rogaška Slatina (središča regionalnega pomena).

$\mathrm{V}$ analizi smo preverili, ali prihaja pri somestjih glede na mobilnost delovne sile tudi do dopolnjevanja centralnih funkcij ter ali somestja, opredeljena v Strategiji prostorskega razvoja Slovenije (2004), na podlagi dopolnjevanja funkcij še vedno obstajajo. Glede na zaznano dopolnjevanje smo v analizo vključili tudi somestje Gornja Radgona-Radenci, ki ga na podlagi mobilnosti delovne sile ne moremo opredeliti kot somestje, prav tako ni bilo navedeno v Strategiji prostorskega razvoja Slovenije (2004).

Med kraje, ki jih z vidika funkcij opredelimo kot somestja, lahko nedvomno uvrstimo:

- Koper-Izola-Piran: Koper ima med tremi mesti najvišjo stopnjo centralnosti, prav tako to velja za večino njegovih področnih funkcij (šolstvo, uprava, sodstvo) z izjemo zdravstva, kjer ima višjo stopnjo Izola (zaradi splošne bolnišnice); mesta si delijo tudi funkcije oziroma sedeže institucij, ki smo jih dodatno zajeli za analizo gravitacijskih območij;

- Brežice-Krško-Sevnica: Brežice in Krško imata najvišje funkcije na področju šolstva (fakulteta), samo Brežice na področju zdravstva (splošna bolnišnica), samo Krško pa na ravni sodstva (okrožno sodišče); med osnovnimi funkcijami za določitev stopnje centralnosti Sevnica nima izstopajoče funkcije, je pa tam sedež GURS in ZRSZ, kamor gravitirajo tudi prebivalci Krškega in Brežic;

Preglednica 2: Matrika naselij v somestjih in njim pripadajočih centralnih funkcij. Višje število označuje višjo stopnjo centralnosti funkcije, skladno $z$ opredelitvijo ravni centralnih naselij: 1 - nacionalno središče mednarodnega pomena, 2 - središče nacionalnega pomena, 3 - središče regionalnega pomena, 4 - središče medobčinskega pomena, 5 - sredičče lokalnega pomena, 6-središče vicinalnega pomena, - ni funkcije. $>$ str. 58-61

Slika 2: Somestja na podlagi centralnih funkcij. $>$ str. 62 


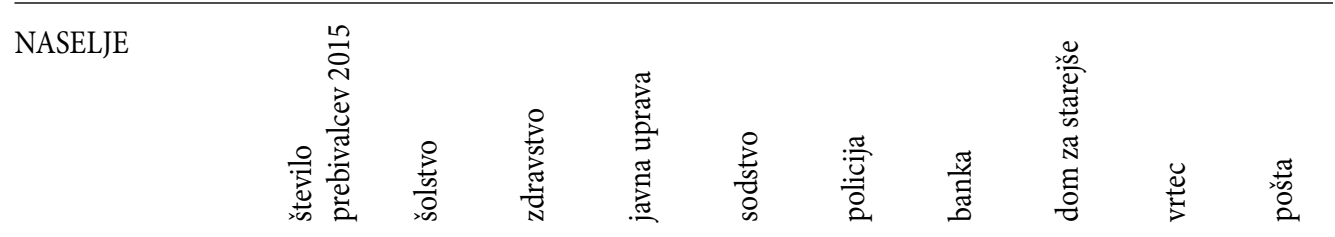

Ajdovščina

Vipava

6596

$\begin{array}{llll}6596 & 3 & 4 & 4 \\ 1946 & 3 & - & 5\end{array}$

8542

Bled

Radovljica

Jesenice

Kranjska Gora

5120

5997

13.031

1556

25.704

Bovec

Kobarid

1593

1115

2708

Brežice

665

Sevnica

7152

4534

18.337

Celje

Žalec

37.540

4812

42.352

Črna na Koroškem 2274

Mežica

Prevalje

Ravne na Koroškem

Slovenj Gradec

Dravograd

3199

$4593 \quad 5 \quad 5$

$\begin{array}{llll}6720 & 2 & 4 & 4\end{array}$

$\begin{array}{lll}7477 & 2 & 2 \\ 3236 & 5 & 4\end{array}$

$3236 \quad 5$

27.499

Metlika

Črnomelj

Semič

3243

569

5694

10.911

Zagorje ob Savi

Trbovlje

Hrastnik

6274

14.165

5205

25.644

Koper

Piran

25.45

11.18

3975

40.622

Kidričevo

Ptuj

1178

17.810

18.988

\begin{tabular}{lll}
5 & 53 & 4 \\
\hline 694 & 3 & 4
\end{tabular}

\begin{tabular}{lllllll}
4 & 4 & 4 & 5 & 4 & 6 & 5 \\
5 & - & - & 5 & - & 6 & 5 \\
\hline
\end{tabular}




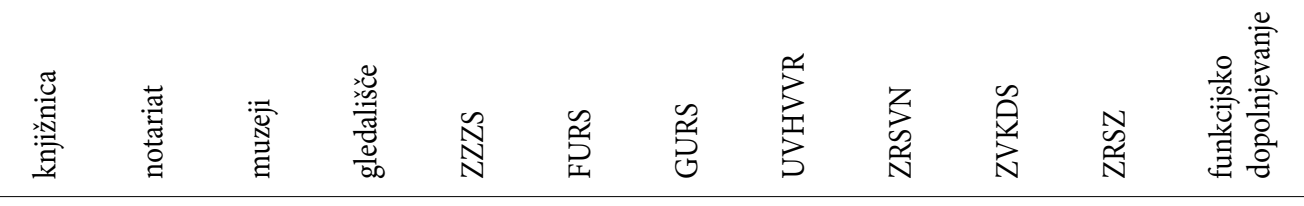

\begin{tabular}{llllllllllll}
4 & 4 & 4 & - & 4 & 4 & 4 & - & - & - & 4 \\
\hline- & - & - & - & - & - & - & - & - & - & - \\
\hline
\end{tabular}

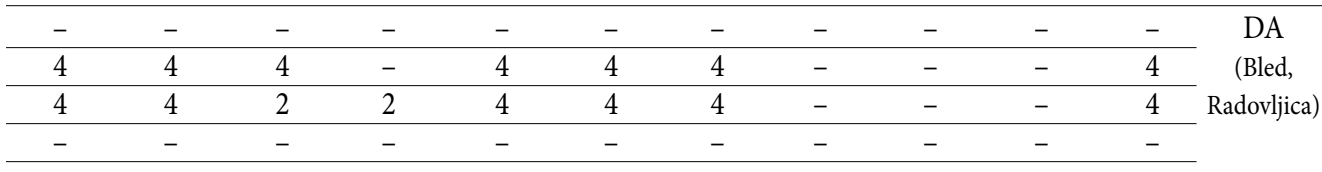

\begin{tabular}{lllllllllll}
- & - & - & - & - & - & - & - & - & - & - \\
\cline { 1 - 1 } & - & 4 & - & - & - & - & - & - & - & - \\
& & & & & & & &
\end{tabular}

\begin{tabular}{lllllllllll}
\hline 4 & 4 & 2 & - & 4 & 3 & 4 & - & - & - & 4 \\
\hline 4 & 4 & 4 & - & 3 & 4 & 4 & - & - & - & 4 \\
\hline 4 & 4 & - & - & 4 & 4 & 3 & - & - & - & 3 \\
\hline
\end{tabular}

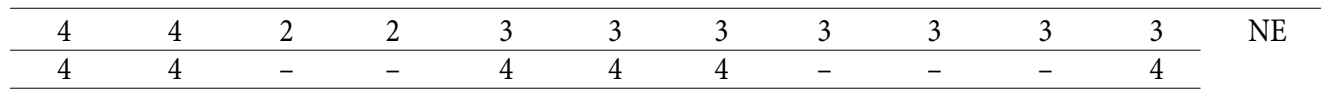

\begin{tabular}{|c|c|c|c|c|c|c|c|c|c|c|c|}
\hline- & - & - & - & - & - & - & - & - & - & - & $\mathrm{DA}$ \\
\hline - & - & - & - & - & - & - & - & - & - & - & (Ravne, SG, \\
\hline- & - & - & $\begin{array}{lll}- & \\
-\end{array}$ & - & - & - & - & - & - & - & Dravograd) \\
\hline 4 & 4 & - & - & 3 & 4 & 4 & - & - & - & 4 & \\
\hline 4 & 4 & 2 & - & 4 & 4 & 3 & - & - & - & 4 & \\
\hline 4 & - & - & - & - & 3 & - & - & - & - & 4 & \\
\hline 4 & - & 2 & - & 4 & 4 & - & - & - & - & 4 & $\mathrm{DA}$ \\
\hline 4 & 4 & - & - & 4 & 4 & 4 & - & - & - & 4 & (Črnomelj, \\
\hline - & - & - & - & - & - & - & - & - & - & - & Metlika) \\
\hline
\end{tabular}

\begin{tabular}{lllllllllll}
\hline 4 & 4 & - & - & 4 & 4 & - & - & - & - & 4 \\
\hline 4 & 4 & 2 & - & 4 & 4 & 4 & - & - & - & 3 \\
\hline 4 & - & - & - & - & 3 & - & - & - & - & 4 \\
\hline
\end{tabular}

\begin{tabular}{llllllllllll}
\hline 4 & 4 & 2 & 2 & 3 & 3 & 3 & 3 & - & - & 3 & DA \\
\hline 4 & 4 & - & - & 4 & 4 & - & - & 3 & - & 4 \\
\hline 4 & - & 2 & - & 4 & 4 & - & - & - & 3 & 4 \\
\hline
\end{tabular}

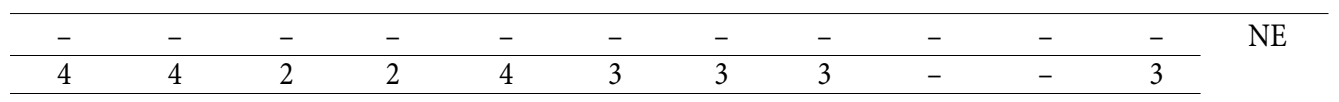




NASELJE

Kočevje

$\begin{array}{rrrrrrrrrr}8398 & 3 & 4 & 4 & 4 & 4 & 5 & 4 & 6 & 5 \\ 3529 & 5 & 4 & 4 & - & 4 & 5 & - & 6 & 5 \\ 11.927 & & & & & & & \end{array}$

\begin{tabular}{|c|c|c|c|c|c|c|c|c|c|c|}
\hline Križevci pri Ljutomeru & 498 & 5 & 5 & 5 & - & - & 5 & 4 & 6 & 5 \\
\hline \multirow[t]{2}{*}{ Ljutomer } & 3343 & 3 & 4 & 4 & 4 & 4 & 5 & 4 & 6 & 5 \\
\hline & 3841 & & & & & & & & & \\
\hline Mozirje & 2025 & 5 & 5 & 4 & - & 4 & 5 & - & 6 & 5 \\
\hline Nazarje & 866 & 5 & 4 & 5 & - & - & 6 & - & 6 & 5 \\
\hline Rečica ob Savinji & 514 & 6 & - & 5 & - & - & 6 & - & 6 & 5 \\
\hline \multirow[t]{2}{*}{ Ljubno ob Savinji } & 1055 & 5 & 5 & 5 & - & 5 & 5 & - & 6 & 5 \\
\hline & 4460 & & & & & & & & & \\
\hline Mirna & 1297 & 5 & 5 & 5 & - & - & 5 & - & 6 & 5 \\
\hline \multirow[t]{2}{*}{ Šentrupert } & 312 & 5 & - & 5 & - & 5 & 6 & - & 6 & 5 \\
\hline & 1609 & & & & & & & & & \\
\hline Muta & 2207 & 3 & 5 & 5 & - & 5 & 5 & - & 6 & 5 \\
\hline \multirow[t]{2}{*}{ Radlje ob Dravi } & 2812 & 5 & 4 & 4 & - & 4 & 5 & 4 & 6 & 5 \\
\hline & 5019 & & & & & & & & & \\
\hline Rogaška Slatina & 5029 & 3 & 5 & 5 & - & 4 & 5 & 4 & 6 & 5 \\
\hline Šmarje pri Jelšah & 1733 & 5 & 4 & 4 & 4 & 4 & 5 & 4 & 6 & 5 \\
\hline
\end{tabular}

\begin{tabular}{lllllllllll}
\hline Slovenske Konjice & 4973 & 3 & 4 & 4 & 4 & 4 & 5 & 4 & 6 & 5 \\
\hline Zreče & 2884 & 3 & 5 & 5 & - & - & 5 & - & 6 & 5 \\
\cline { 2 - 9 }
\end{tabular}

\begin{tabular}{lrlllllllll}
\hline Šempeter pri Gorici & 3729 & 3 & 2 & 5 & - & 5 & 5 & - & 6 & 5 \\
\hline Nova Gorica & 12.985 & 3 & 4 & 4 & 2 & 4 & 5 & 4 & 6 & 5 \\
\cline { 2 - 9 }
\end{tabular}

\begin{tabular}{lllllllllll}
\hline Šentjur & 4825 & 3 & 4 & 4 & 4 & 4 & 5 & 4 & 6 & 5 \\
\hline Štore & 1931 & 3 & 5 & 5 & - & 5 & 6 & 4 & 6 & 5 \\
\cline { 2 - 10 }
\end{tabular}

\begin{tabular}{lrlllllllll}
\hline Šoštanj & 2891 & 5 & 5 & 5 & - & 5 & 5 & - & 6 & 5 \\
\hline Velenje & 25.122 & 3 & 4 & 4 & 4 & 4 & 5 & 4 & 6 & 5 \\
\cline { 2 - 11 }
\end{tabular}

\begin{tabular}{lllllllllll}
\hline Kamnik & 13.803 & 3 & 4 & 4 & 4 & 4 & 5 & 4 & 6 & 5 \\
\hline Domžale & 12.792 & 3 & 4 & 4 & 4 & 4 & 5 & 4 & 6 & 5 \\
\cline { 2 - 9 } & 26.595 & & & & & & & & &
\end{tabular}

\begin{tabular}{lllllllllll}
\hline Gornja Radgona & 3090 & 5 & 4 & 4 & 4 & 4 & 5 & 4 & 6 & 5 \\
\hline Radenci & 2154 & 3 & 5 & 5 & - & - & 5 & 4 & 6 & 5 \\
\cline { 2 - 9 }
\end{tabular}




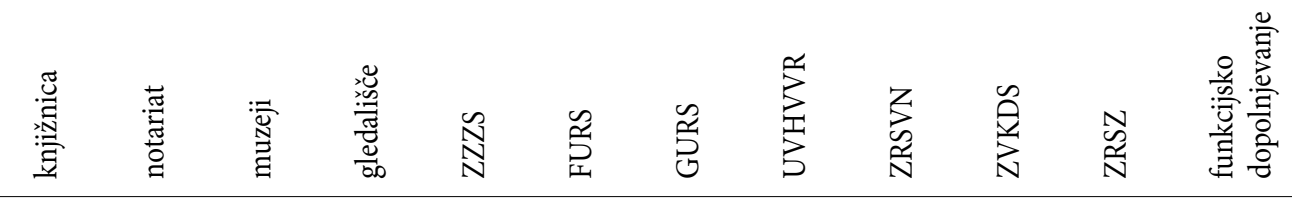

\begin{tabular}{lllllllllll}
4 & 4 & 2 & - & 4 & 3 & 4 & - & - & - & 4 \\
\hline 4 & - & 4 & - & 4 & 4 & - & - & - & - & 4 \\
\hline
\end{tabular}

\begin{tabular}{ccccccccccc}
\hline- & - & - & - & - & - & - & - & - & - & - \\
\hline 4 & 4 & - & - & 4 & 4 & 4 & - & - & - & 4 \\
\cline { 1 - 7 }
\end{tabular}

\begin{tabular}{|c|c|c|c|c|c|c|c|c|c|c|c|}
\hline 4 & - & - & - & 4 & 4 & 4 & - & - & - & 4 & DA \\
\hline- & - & - & - & - & - & - & - & - & - & - & (Mozirje, \\
\hline- & - & - & - & - & - & - & - & - & - & - & Nazarje, \\
\hline - & - & - & - & - & - & - & - & - & - & - & Ljubno) \\
\hline
\end{tabular}

\begin{tabular}{|c|c|c|c|c|c|c|c|c|c|c|c|}
\hline- & - & - & - & - & - & - & - & - & - & - & $\mathrm{NE}$ \\
\hline- & - & - & - & - & - & - & - & - & - & - & \\
\hline - & - & - & - & - & - & - & - & - & - & - & \multirow[t]{2}{*}{$\mathrm{DA}$} \\
\hline 4 & 4 & - & - & 4 & 4 & - & - & - & - & 4 & \\
\hline 4 & - & - & - & - & - & - & - & - & - & - & \multirow[t]{2}{*}{$\mathrm{DA}$} \\
\hline 4 & 4 & - & - & 4 & 4 & 4 & - & - & - & 4 & \\
\hline 4 & 4 & - & - & 4 & 4 & 4 & - & - & - & 4 & \multirow[t]{2}{*}{$\mathrm{NE}$} \\
\hline- & - & - & - & - & - & - & - & - & - & - & \\
\hline- & - & - & - & - & - & 3 & - & - & - & - & \multirow[t]{2}{*}{$\mathrm{DA}$} \\
\hline 4 & 4 & 2 & 1 & 3 & 3 & - & 3 & 3 & 3 & 3 & \\
\hline 4 & 4 & - & - & 4 & 4 & 4 & - & - & - & 4 & \multirow[t]{2}{*}{$\mathrm{NE}$} \\
\hline- & - & - & - & - & - & - & - & - & - & - & \\
\hline- & - & - & - & - & - & - & - & - & - & - & \multirow[t]{2}{*}{$\mathrm{NE}$} \\
\hline 4 & 4 & 4 & - & 4 & 3 & 3 & - & - & - & 3 & \\
\hline 4 & 4 & 4 & - & 4 & 4 & 4 & - & - & - & 4 & \multirow[t]{2}{*}{$\mathrm{NE}$} \\
\hline 4 & 4 & - & - & 4 & 4 & 4 & - & - & - & 4 & \\
\hline 4 & 4 & - & - & 4 & 4 & 4 & - & - & - & 4 & \multirow[t]{2}{*}{$\mathrm{DA}$} \\
\hline- & - & - & - & - & - & - & - & - & - & - & \\
\hline
\end{tabular}




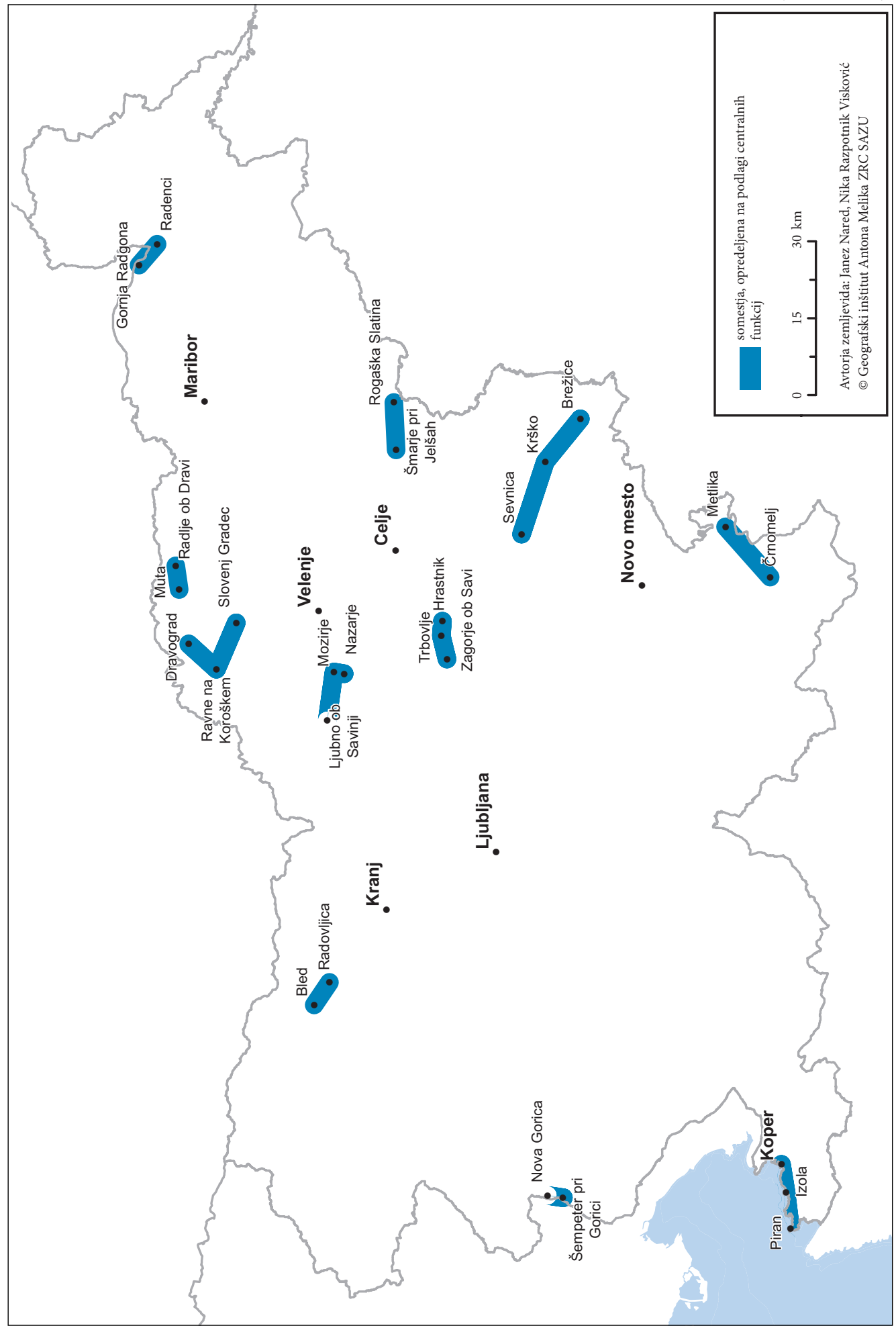


- Dravograd-Ravne na Koroškem-Slovenj Gradec: Slovenj Gradec ima v večini področij višje ali enake stopnje funkcij; v Ravnah na Koroškem je sedež ZZZS, v Dravogradu pa sedež FURS-a; dodatna tri naselja, ki smo jih v somestje vključili na podlagi trga delovne sile, se razen deloma Prevalj, ki imajo dom za starejše občane, s somestjem, opredeljenim v Strategiji prostorskega razvoja Slovenije (2004), funkcijsko ne dopolnjujejo;

- Rogaška Slatina-Šmarje pri Jelšah: Rogaška Slatina ima višjo funkcijo na področju šolstva, Šmarje pri Jelšah pa zdravstva, uprave in sodstva;

- Črnomelj-Metlika: Črnomelj ima višjo stopnjo na področju šolstva ter sodstva, ima tudi notariat, Metlika ima policijo in muzej, Semič, ki smo ga dodali na podlagi trga delovne sile, pa večjih dveh naselij funkcijsko ne dopolnjuje;

- Nova Gorica-Šempeter pri Gorici: Nova Gorica ima povsod višjo ali enako stopnjo funkcije razen pri zdravstvu - v Šempetru pri Gorici je splošna bolnišnica;

- Gornja Radgona-Radenci: Radenci imajo višjo stopnjo na področju šolstva, na drugih področjih ima višjo ali enako stopnjo Gornja Radgona;

Med preostalimi somestji, ki smo jih opredelili na podlagi trga dela, se funkcijsko dopolnjujeta še Muta in Radlje ob Dravi.

Manj jasno je dopolnjevanje s funkcijami na primeru somestij:

- Jesenice-Radovljica-Bled: Jesenice imajo višje ali enake stopnje funkcij v primerjavi z Radovljico in Bledom; Bled ima v primerjavi z Radovljico višjo stopnjo na področju šolstva in zdravstva, slednja pa ima knjižnico in dom za upokojence; glede na obstoječe funkcije je opredelitev teh mest kot somestje vprašljivo, saj Radovljica in Bled z ničemer ne dopolnjujeta Jesenic; pomembnejšega funkcijskega dopolnjevanja tudi ne nudi Kranjska Gora;

- Trbovlje-Zagorje ob Savi-Hrastnik: Trbovlje ima najvišje ali enako visoke stopnje funkcij na vseh področjih, Zagorje ima v primerjavi s Hrastnikom višjo stopnjo na področju šolstva, v Hrastniku pa je sedež FURS-a; glede Trbovelj se tako postavlja podobno vprašanje, saj Zagorje v ničemer ne dopolnjuje Trbovelj, Hrastnik pa le s sedežem FURS-a.

- Mozirje-Nazarje-Rečica ob Savinji-Ljubno: v somestju, kjer izstopa Mozirje, je s funkcijskega vidika pomembno še Nazarje, kjer je zdravstveni dom, Ljubno ima banko, medtem ko Rečica ob Savinji dodatnih funkcij nima.

V somestju Domžale-Kamnik funkcijskega dopolnjevanja ni, prav tako ne v ostalih somestjih, ki smo jih določili na podlagi trga dela. Pri Bovcu in Kobaridu sicer ima Bovec policijsko postajo, Kobarid pa muzej, vendar je dopolnjevanje navidezno, saj policijska postaja v Bovcu ne pokriva območja Kobarida.

\section{Sinteza in razprava}

Analize so pokazale, da je somestij, opredeljenih na podlagi mobilnosti delovne sile, več kot tistih, ki jih lahko opredelimo na podlagi dopolnjevanja funkcij. Prav tako je število mest v somestju večje, če upoštevamo mobilnost delovne sile. Zaznamo tudi, da je povezanost trga dela večja na območjih z linearno razporeditvijo naselij (doline rek, obala, obmejna območja), saj je zaradi oteženega prehoda $\mathrm{v}$ posamezne smeri osredotočenost na lažje prehodna območja večja, posledično v tej smeri potuje tudi več delovne sile.

Somestje Koper-Izola-Piran lahko opredelimo kot mrežno somestje, saj prihaja do pretoka delovne sile med vsemi tremi kraji, prav tako se vsa naselja tudi funkcijsko dopolnjujejo. Vodilno mesto v somestju je Koper, ki prednjači tako upoštevaje delovno silo, kot tudi funkcije. Močnejše povezanosti z Ankaranom in Portorožem, ki ju v to somestje uvršča Kokole (1971), ne moremo potrditi, smo pa v analizi stičnih naselij, ki nakazujejo na močno prostorsko povezanost dveh ali več naselij, kot stično naselje opredelili naselja Lucija, Portorož in Piran, kar pomeni, da jih je glede na gostoto poselitve pri 
preučevanju oskrbe s centralnimi funkcijami smiselno obravnavati kot eno naselje. Na enak način lahko k Izoli priključimo Jagodje (Nared, Bole in Ciglič 2016).

$Z$ vidika trga dela razmeroma veliko somestje Črna na Koroškem-Mežica-Prevalje-Ravne na Koroškem-Slovenj Gradec-Dravograd se glede na centralne funkcije dopolnjuje le med zadnjimi tremi naselji, torej tako, kot je navedeno v Strategiji prostorskega razvoja Slovenije (2004). Z vidika dopolnjevanja funkcij tudi težko pričakujemo, da bi ostala tri naselja razen Prevalj, ki jih skupaj z Dobjo vasjo in Stražiščem lahko priključimo Ravnam na Koroškem (Nared, Bole in Ciglič 2016), z vidika funkcij prevzela vidnejšo vlogo, je pa tesno povezanost trga dela vsekakor treba upoštevati tako pri razvoju infrastrukture kot pri gospodarskem razvoju.

Zgornjegorenjsko somestje Bled-Radovljica-Jesenice-Kranjska Gora tudi kaže na pomembno prepletenost omenjenih gospodarskih središč, vendar pa s funkcijskega vidika Jesenice močno prevladujejo ter jih ostali kraji funkcijsko ne dopolnjujejo. Na podlagi centralnih funkcij tako lahko potrdimo le somestje Radovljica-Bled. Z vidika ožje opredelitve mest lahko k Radovljici prištejemo še Lesce, saj ju lahko obravnavamo kot stično naselje (Nared, Bole in Ciglič 2016).

Tako $\mathrm{z}$ vidika trga dela kot centralnih funkcij je močno povezano somestje Brežice-Krško-Sevnica, h kateri lahko prištejemo še Dolnji Boštanj.

Zasavsko somestje Zagorje-Trbovlje-Hrastnik prav tako lahko opredelimo kot somestje, čeprav skladno z metodologijo ne moremo reči, da Zagorje funkcijsko dopolnjuje Trbovlje, lahko pa to trdimo za razmerje med Trbovljami in Hrastnikom ter Hrastnikom in Zagorjem.

Na podlagi obeh meril lahko o somestju govorimo tudi v primeru Črnomlja in Metlike, katerima bi $z$ vidika trga dela lahko dodali še Semič.

Z vidika obeh meril se dopolnjujejo še somestja Rogaška Slatina-Šmarje pri Jelšah, Muta-Radlje ob Dravi, Mozirje-Nazarje-Ljubno ob Savinji-Rečica ob Savinji (slednja le z vidika trga dela), ter somestje Nova Gorica-Šempeter pri Gorici, ki pa bi ju s še nekaj naselji lahko opredelili kot stično naselje.

Glede na metodologijo (Nared, Bole, Ciglič 2016) lahko kot stično naselje opredelimo tudi Domžale in Kamnik, kjer pa ne prihaja do večje prepletenosti trga dela, prav tako ne do dopolnjevanja z vidika centralnih funkcij, zato ju glede na merila nikakor ne moremo uvrstiti med somestja.

V preostalih z vidika trga delovne sile zaznanih somestjih do dopolnjevanja funkcij ne prihaja, zato jih v klasičnem smislu dopolnjevanja funkcij ne moremo opredeliti kot somestija, je pa v prihodnje smiselno razmišljati o njihovem tesnejšem povezovanju tudi na tej ravni.

$\mathrm{Z}$ razvojnega vidika bi v prihodnje vidnejšo vlogo lahko imeli zlasti savinjsko-šaleški pari naselij (Celje-Žalec, Velenje-Šoštanj in Šentjur-Štore), saj je zlasti območje med Celjem in Velenjem z vidika povezovanja med podjetji eno funkcijsko najbolj prepletenih (Nared 2005; 2006), Dimitrovska Andrews in sodelavci (2001) pa v tej povezavi govorijo kar o savinjski urbani regiji.

$\mathrm{Z}$ vidika navajanja somestij v Strategiji prostorskega razvoja Slovenije (2004) lahko ugotovimo, da so v večini primerov opredelitve ustrezne, niso pa celovite in sistematične. Težave so zlasti v opredeljevanju somestja Jesenice-Radovljica ter Domžale-Kamnik, pri katerem je prvo vsaj deloma neustrezno, pri drugem pa somestja ni niti z vidika dopolnjevanja funkcij niti z vidika trga dela. Na drugi strani bi bilo smiselno v Strategiji opredeliti dodatna somestja, kot so Črnomelj-Metlika-(Semič), Nova Gorica-Šempeter pri Novi Gorici, Gornja Radgona-Radenci ter Muta in Radlje ob Dravi, morda pa tudi sicer populacijsko zelo šibko Zgornjesavinjsko somestje. Zanimivo je, da so bila nekatera od teh somestij opredeljena v Konceptu prostorskega razvoja Slovenije (Dimitrovska Andrews in sodelavci 2001), a nato kot taka niso bila prenešena v Strategijo (na primer belokranjsko somestje). Hkrati pa je bilo v Konceptu opredeljenih nekaj somestij, ki jih sedaj kot taka ne moremo potrditi (Postojna-Pivka).

Glede na to, da so bila somestja v preteklosti že vključena v posamezne strateške dokumente (Filipčič in Kržišnik 1973; Hudoklin in sodelavci 2003; Strategija ... 2004; Miklavčič in sodelavci 2014), bi bilo njihove opredelitve smiselno postaviti na skupni imenovalec ter jih umestiti v širši mednarodni okvir. V tujini je bilo v zadnjem času narejenih več analiz z vidika policentrizma, kjer so v ospredju 
mestne regije in povezave med mesti, vendar Meijers (2008) opozarja, da somestij ne moremo neposredno primerjati s policentrizmom, saj so somestja koncept, ki predpostavlja veliko večjo prepletenost tokov ter medsebojno dopolnjevanje med kraji. Pri tem tuja literatura za opredeljevanje somestij omenja različne vidike mobilnosti ter funkcijskih povezav, ki se kažejo v pretoku dobrin in informacij (na primer: ESPON 2004; 2005; 2007; Cattan 2007; Neal 2013), vendar smo v Sloveniji zaradi skromnih podatkov $v$ tovrstnih raziskavah zelo omejeni.

V pojmovnem smislu uvajamo dva nova termina, to je »mrežno somestje« in »verižno somestje«. Čeprav lahko mrežno somestje povezujemo s številnimi že uveljavljenimi pojmi, kot so regijsko mesto, mestna regija ali aglomeracija (Drozg 2006), se vendarle od njih vsebinsko razlikuje. Pri regijskem mestu govorimo o gospodarski suburbanizaciji posameznega mesta, pri mestni regiji o regiji, funkcijsko vezani na posamezno mesto. Pojmovno še najbližje bi bil pojem aglomeracija, ki izhaja iz dveh ali več mest, vendar pa je v vsebinskem smislu veliko kompleksnejša. Mrežno in verižno somestje namreč le nakazujeta obliko povezanosti med mesti, ne prikazujeta pa procesa poselitvenega in gospodarskega zgoščanja na določenem območju, kar je sicer značilno za aglomeracijo.

Prav iz omenjene kakovostne razlike opredeljevanja somestij v Sloveniji (glede na že uveljavljene pojme) lahko nakažemo možne nadgradnje uporabljene metodologije. Ta sicer upoštevaje omejitve s podatki, na sistematičen način predstavi somestja v Sloveniji, popolnoma pa pusti ob strani druge vidike razvoja somestij, kot so gospodarska, finančna, informacijska in družbena povezanost med mesti.

\section{Sklep}

V prispevku smo se osredotočili na opredelitev somestij v Sloveniji, pri čemer smo želeli izvedeti, katera somestja lahko opredelimo na podlagi trga dela oziroma mobilnosti delovne sile, katera somestja lahko opredelimo na podlagi dopolnjevanja funkcij in v kolikšni meri se zaznana somestja razlikujejo od somestij, opredeljenih v Strategiji prostorskega razvoja Slovenije iz leta 2004. Na podlagi mobilnosti delovne sile smo določili 33 parov naselij, ki smo jih nato združili v 20 somestij, jim dodali manjkajoča somestja iz Strategije prostorskega razvoja Slovenije (2004) ter preverili povezanost med naselji še z vidika dopolnjevanja centralnih funkcij.

Ugotovili smo, da se na podlagi mobilnosti delovne sile oblikujejo obsežnejša in številnejša somestja, kot jih lahko opredelimo na podlagi dopolnjevanja centralnih funkcij. Prav tako smo ugotovili, da je opredelitev somestij v Strategiji prostorskega razvoja Slovenije (2004) razmeroma ustrezna, ne pa celovita in dosledna. Z izjemo somestja Domžale-Kamnik, kjer ne prihaja do medsebojnega prepletanja ter somestja Jesenice-Radovljica, kjer Radovljica v ničemer ne dopolnjuje Jesenic, a je na drugi strani zaznati povezanost Radovljice z Bledom, so somestja ustrezno opredeljena. Lahko pa bi jim tako glede mobilnosti delovne sile kot dopolnjevanja funkcij dodali še somestja Črnomelj-Metlika-(Semič), Nova Gorica-Šempeter pri Novi Gorici, Gornja Radgona-Radenci ter Muta-Radlje ob Dravi, morda pa tudi sicer populacijsko šibkejše Zgornjesavinjsko somestje (Mozirje-Nazarje-Rečica ob Savinji-Ljubno).

Z opravljeno analizo smo opredelitev somestij postavili v jasnejši metodološki okvir, s katerim je mogoče somestja bolj natančno opredeliti. Pri tem smo do sedaj uveljavljeni pristop dopolnjevanja centralnih funkcij nadgradili $z$ analizo mobilnosti delovne sile, s čimer smo opredeljevanje somestij postavili $\mathrm{v}$ širši kontekst ter nakazali možne smeri prostorskega razvoja (širjenja) somestij.

Zahvala: Študija je bila izvedena v okviru projekta Policentrično omrežje središč in dostopnost prebivalstva do storitev splošnega in splošnega gospodarskega pomena, ki ga je financiralo Ministrstvo Republike Slovenije za okolje in prostor. 


\section{Viri in literatura}

Bole, D. 2004: Dnevna mobilnost delavcev v Sloveniji. Acta geographica Slovenica 44-1. DOI: http://dx.doi.org/ 10.3986/AGS44102

Cattan, N. (ur.) 2007: Cities and Networks in Europe: A Critical Approach of Polycentrism. Esher.

Cigale, D. 2002: Centralna naselja v Sloveniji in njihova vplivna območja v letu 1999. Geografski vestnik 74-1.

Delovno aktivno prebivalstvo (brez kmetov) po občinah prebivališča in občinah delovnega mesta po spolu, občine, Slovenija, letno. Statistični urad Republike Slovenije. Ljubljana, 2016. Medmrežje: http://pxweb.stat.si/pxweb/Dialog/varval.asp?ma=0723405S\&ti=\&path=../Database/ Dem_soc/07_trg_dela/05_akt_preb_po_regis_virih/10_07234_delovne_migracije/\&lang=2 (30.7.2016).

Dimitrovska Andrews, K., Gologič, M., Gulič, A., Mušič, B. V., Ogrin, D., Pichler Milanovič, N., Plevnik, A., Praper, S., Ravbar, M. 2001: Koncept prostorskega razvoja Slovenije: končno poročilo. Urbanistični inštitut Republike Slovenije. Ljubljana.

Dolgoročni plan SR Slovenije za obdobje od leta 1986 do leta 2000. Uradni list Socialistične republike Slovenije 1/1986. Ljubljana.

Drozg, V. 2006: Regijsko mesto Maribor. Revija za geografijo 1-1.

ESPON 1.1.1: Final report, 2004. Medmrežje: http://www.espon.eu/main/Menu_Projects/ Menu_ESPON2006Projects/Menu_ThematicProjects/ (8.3.2016).

ESPON 1.1.1: Potentials for polycentric development in Europe. Stockholm, 2005. Medmrežje: www.espon.eu/export/sites/.../Polycentricity/fr-1.1.1_revised-full.pdf (3. 3. 2016).

ESPON 1.4.3: Final report, 2007. Medmrežje: http://www.espon.eu/main/Menu_Projects/ Menu_ESPON2006Projects/Menu_StudiesScientificSupportProjects/urbanfunctions.html (8.3.2016).

Filipčič, K., Kržišnik, E. 1973: Koncept gospodarskega, socialnega in regionalnega razvoja Posavja: 1971-1985: zaključni dokument. Raziskovalno poročilo, Region. Brežice.

Hudoklin, J., Nikić, R., Zavodnik Lamovšek, A., Fatur, M., Selak, I., Husak, M., Simič, S., Jankovič, L., Jug, M., Čok, G. 2003: Regionalna zasnova prostorskega razvoja Jugovzhodne Slovenije: zaključno poročilo 3. faze. raziskovalno poročilo, Acer. Novo mesto.

Kokole, V. 1971: Centralni kraji v SR Sloveniji, problemi njihovega omrežja in njihovih gravitacijskih območij. Geografski zbornik 12.

Kokole, V. 1978: Postojna kot regionalno središče. Geografski vestnik 50.

Kokole, V., Kokole, V. 1987: Stanje in perspektive omrežja centralnih naselij na spominskem območju Žumberak-Gorjanci. Geografski vestnik 59.

Medmrežje 1: http://ipop.si/urejanje-prostora/izrazje/somestje_konurbacija/ (17. 8. 2016).

Meijers, E. 2008: Measuring polycentricity and its promises. European Planning Studies 16-9. DOI: http://dx.doi.org/10.1080/09654310802401805

Miklavčič, T., Fonda, M., Jerebic, B., Komac Sušnik, Š., Peršak Cvar, S. 2014: Občinski prostorski akti in namenska raba prostora v Sloveniji. Ministrstvo za infrastrukturo in prostor. Ljubljana.

Nared, J. 2005: Geografski vidiki mreženja podjetij v Sloveniji. Geografski vestnik 77-2.

Nared, J. 2006: Mrežna zasnova lokalnega gospodarstva: primer Savinjsko Šaleške regije. Šaleška in Zgornja Savinjska dolina. Velenje.

Nared, J., Bole, D., Breg Valjavec, M., Ciglič, R., Goluža, M., Kozina, J., Razpotnik Visković, N., Repolusk, P., Rus, P., Tiran, J., Černič Istenič, M. 2016: Policentrično omrežje središč in dostopnost prebivalstva do storitev splošnega in splošnega gospodarskega pomena: končno poročilo. Geografski inštitut Antona Melika ZRC SAZU. Ljubljana.

Nared, J., Bole, D., Breg Valjavec, M., Ciglič, R., Goluža, M., Kozina, J., Razpotnik Visković, N., Repolusk, P., Rus, P., Tiran, J., Černič Istenič, M. 2017: Centralna naselja v Sloveniji leta 2016. Acta geographica Slovenica 57-2. DOI: http://dx.doi.org/10.3986/AGS.4606 
Nared, J., Bole, D., Ciglič, R. 2016: Določanje stičnih naselij za vrednotenje opremljenosti naselij s storitvami splošnega in splošnega gospodarskega pomena. Prostorski podatki. GIS v Sloveniji 13. Ljubljana.

Neal, P. Z. 2013: The Connected City: How Networks are Shaping the Modern Metropolis. New York. Pogačnik, A., Sitar, M., Lavrač, I., Kobal, J., Peterlin, M., Zavodnik Lamovšek, A., Drobne, S., Konjar, M., Trobec, B., Soss, K., Pichler Milanovič, N., Pogačar, K., Kešeljevič, A., Kosi, A., Miklavčič, T., Zakrajšek, U., Strmšnik, K., Stres, A. 2010: Analiza razvojnih virov in scenarijev za modeliranje funkcionalnih regij. Elaborat, Fakulteta za gradbeništvo in geodezijo Univerze v Ljubljani, Fakulteta za gradbeništvo Univerze v Mariboru, Ekonomska fakulteta Univerze v Ljubljani, OIKOS d. o. o., svetovanje za razvoj, IPoP, inštitut za politike prostora. Ljubljana, Maribor.

Ravbar, M., Vrišer, I., Plut, D., Šircelj, V., Cigale, D. 2001: Omrežje naselij in prostorski razvoj Slovenije. Elaborat, Geografski inštitut Antona Melika ZRC SAZU. Ljubljana.

Strategija prostorskega razvoja Slovenije, 2004. Medmrežje: http://www.mop.gov.si/fileadmin/mop.gov.si/ pageuploads/publikacije/sprs_slo.pdf (24.3.2016).

Vresk, M. 2002: Grad i urbanizacija - Osnove urbane geografije. Zagreb.

Vrišer, I. 1988: Centralna naselja v SR Sloveniji leta 1987. Geografski zbornik 28. Ljubljana.

\section{Summary: Conurbations in Slovenia}

(translated by DEKS d. o. o.)

This article focuses on defining conurbations in Slovenia, whereby the goal was to determine which conurbations can be defined based on the labor market or commuting for work, which conurbations can be defined based on complementary functions, and the extent to which the conurbations identified differ from conurbations as defined in the 2004 Spatial Development Strategy of Slovenia.

For defining conurbations based on commuting, we took into account the 2015 statistical data on the active working population (excluding farmers) by municipality of residence and municipality of employment (Delovno aktivno ... 2016). The data are deficient because they are available only at the municipal level, which we interpreted for the analysis as data relevant for the municipal center. In doing so, we disregarded the labor market within an individual municipality, which impacts the accuracy of the results especially in municipalities containing several important centers, where individual settlements could hypothetically show a certain degree of connection with other settlements inside the same municipality or with settlements in neighboring municipalities.

The point of departure for defining conurbations in this way is that two municipalities/settlements (towns) are connected on the basis of commuting, whereby it is not sufficient for only one municipality/settlement to provide jobs to the workforce from the other municipality/settlement, but that the flow of workers must also go in the opposite direction, so that the other municipality/settlement provides jobs to a comparable share of the workforce from the first municipality/settlement. Based on an analysis of the data and certain previous studies on commuting (Bole 2004), two thresholds were defined: $10 \%$ and $5 \%$.

The $10 \%$ threshold means that at least $10 \%$ of the active working population of municipality/settlement A commutes from municipality/settlement $\mathrm{A}$ to municipality/settlement $\mathrm{B}$, and that at the same time at least $10 \%$ of the active working population of municipality/settlement $\mathrm{B}$ commutes from municipality/settlement B to municipality/settlement A.

The $5 \%$ threshold means that at least $5 \%$ of the active working population of municipality/settlement A commutes from municipality/settlement $\mathrm{A}$ to municipality/settlement $\mathrm{B}$, and that at the same time at least $5 \%$ of the active working population of municipality/settlement $B$ commutes from municipality/settlement B to municipality/settlement A.

In the next step, the resulting pairs of settlements were connected with each other if one or more of the settlements were included in multiple pairs. When all of the settlements included were connected 
in pairs (at least three), the conurbation was defined as a network conurbation, and when all of the settlements were not connected with all of the others this was defined as a chain conurbation.

In defining conurbations based on central functions, we proceeded from services of general interest; that is, services that provide for the population's basic needs. We primarily took into account functions based on which we defined the settlements' level of centrality (e.g., education, healthcare, administration, and judicial services), and at the same time we checked certain additional functions of central importance (e.g., headquarters of institutions).

The point of departure for defining conurbations in this way is that the settlements mutually complement each other by providing individual functions. For this we checked conurbations with regard to commuting and conurbations as defined in the 2004 Spatial Development Strategy of Slovenia, and we added some additional conurbations that we were able to identify based on an analysis (Nared et al. 2016; 2017). The key criterion for defining conurbations was that an individual settlement in a conurbation must complement other settlements in the conurbation with at least one function.

In the third step, we combined both of the previous definitions of conurbations and worked out a joint assessment of conurbations.

Based on commuting, we defined thirty-three pairs of settlements, which we then combined into twenty conurbations, to which we added missing conurbations from the 2004 Spatial Development Strategy of Slovenia and then checked the connection between the settlements with regard to complementary central functions.

We determined that conurbations defined based on commuting are more extensive and more numerous than those defined based on complementary central functions. We also determined that the definition of conurbations in the Spatial Development Strategy of Slovenia is relatively appropriate, but not comprehensive and consistent. With the exception of the conurbation of Domžale-Kamnik (where there is no overlap) and the conurbation of Jesenice-Radovljica (where Radovljica does not complement Jesenice in any way, but it is possible to identify a connection between Radovljica and Bled), the conurbations are suitably defined; however, based on both mobility and complementary functions, it would be possible to add Črnomelj-Metlika-(Semič), Nova Gorica-Šempeter pri Novi Gorici, Gornja Radgona-Radenci, and Muta-Radlje ob Dravi, as well as a less populous conurbation in the Upper Savinja Valley (Mozirje-Nazarje-Rečica ob Savinji-Ljubno).

The analysis carried out allowed us to place the definition of conurbations into a clearer methodological framework, with which it is possible to define conurbations more precisely. In this, we improved the established approach of using complementary central functions by adding commuting, which places the definition of conurbations in a broader context and indicates possible directions for the spatial development (or spread) of conurbations. 